This is a self-archived version of an original article. This version may differ from the original in pagination and typographic details.

Author(s): Sivunen, Anu

Title: Twitter : viestinnän vai vuorovaikutuksen alusta?

Year: 2018

Version: Published version

Copyright: @ Kirjoittaja ja Prologos ry

Rights:

Rights url:

Please cite the original version:

Sivunen, A. (2018). Twitter : viestinnän vai vuorovaikutuksen alusta?. Prologi : puheviestinnän vuosikirja, 2018, 72-74. 


\begin{tabular}{rr}
\hline \hline Kirja-arvio & \\
\hline & $\begin{array}{r}\text { Prologi - puheviestinnän } \\
\text { vuosikirja 2018 }\end{array}$
\end{tabular}

\section{Twitter - viestinnän vai vuorovaikutuksen alusta?}

Anu Sivunen

Professori

Jyväskylän yliopisto, Kieli- ja viestintätieteiden laitos

anu.e.sivunen@jyu.fi

Pekka Isotalus, Jari Jussila \& Janne Matikainen, 2018. Twitter viestintänä - ilmiöt ja verkostot, Vastapaino, 296 sivua.

Vastapainon julkaisema Twitter viestintänä - Ilmiöt ja Verkostot -kirja (toim. Isotalus, P., Jussila J. \& Matikainen, J.) tarjoaa monipuolisen katsauksen Twitterin käyttöön ja Twitterissä käytävään viestintään eri konteksteissa. Kirjan toimittajat ja kirjoittajat edustavat melko laajasti suomalaista yliopistokenttää ja eri tieteenaloja. Twitterin nostaessa suosiotaan erityisesti Suomessa julkisen ja yhteiskunnallisenkin keskustelun paikkana on aiheeseen keskittyvälle, suomenkieliselle kirjalle varmasti tilausta. ja vaikuttaminen Twitterissä muodostaa kirjan suurimman osion ja kertookin aihealueen tutkimuksen suosiosta Suomessa. Kolmas osio on otsikoitu Organisaatiot ja uutismedia Twitterissä ja se keskittyy vahvasti organisaatioiden Twitterin käyttöön toisaalta niiden ulkoise viestinnän ja maineen näkökulmasta ja toisaalta erityisesti uutisorganisaatioiden piirteisiin Twitterin hyödyntämisessä. Kirjan neljäs osio Twitterin tutkimus, poikkeaa muista osioist teemoiltaan kuvaten Twitterin hyödyntämistä tutkimusaineiston keräämiseen ja avaten erilaisten internet-aineistojen analyysitapoja.

Kirjan artikkelit on koostettu suurelta osin Tampereen yliopistossa tammikuussa 2016 järjestetyn seminaarin pohjalta. Tämä näkyy osittain kirjan sisällöissä ja aihevalinnoissa. Voikin sanoa, että kirja käsittelee Twitteria suomalaisesta (viestinnän) tutkimuksesta käsin ja kirjan lukujen teemat ovat valikoituneet siitä näkökulmasta, millaista tieteellistä ja populaarimpaa tutkimusta Suomessa on kirjan kirjoitushetkellä Twitteristä tehty. Esimerkiks Twitterin käyttöä työntekijöiden tai organisaatioiden vuorovaikutuksen välineenä ei kirjass käsitellä juuri lainkaan, lukuunottamatta poliittisen viestinnän näkökulmaa kansanedustajien ja toimittajien Twitter-käyttäytymisestä (luvu 3 ja 4), suomalaiskaupunkien Twitter-tilien sisällönanalyysia (luku 9) sekä luvun 10 tuloksia toimittajien ja mediaorganisaatioiden Twitter-viestinnästä. Kuitenkin kansainvälistä tutkimusta on olemassa esimerkiksi työntekijälähettilyydestä, työntekijöiden itsensä esittämisestă sekä vaikutelman- ja yksityisyydenhallinnast Twitterissä ja tätä tutkimusta olisi ollut kiinnostavaa saada kirjaan mukaan. Lisäksi kirjaan olisi kaivannut laajempaa katsausta Twitterin ja sosiaalisen median tutkimuksen etiikkaan. Osassa kirjan lukuja esimerkiksi käytettiin aineistona julkaistuja tviittejä käyttäjien tunnistetietojen kanssa ilman, että tätä käytäntöä tai sen eettisyyttä mitenkään pohdittiin. Kirjan tutkimusosioon olisikin hyvin mahtunut enemmän pohdintaa siitä, miten Twitterissä julkaistuja päivityksiä voi käyttää tutkimusmateriaalina ja kuinka tunnistettavia käytetyt tviitit voivat erilaisiin tutkimustarkoituksiin olla. Sosiaalisen median aineistoihin ja niiden käyttöön kohdistuu nykyisin eurooppalaisen lainsäädännönkin myötä uusia vaatimuksia, joita ei ehkä kirjaa tehtäessä osattu vielä tunnistaa, mutta pelkästään jo yleisiä, internet-aineistojen hyödyntämistä eettisyyden näkökulmasta problematisoivia puheenvuoroja olisi suonut olevan kirjassa enemmän.

Artikkelit vaihtelevat myös tieteelliseltä syvyydeltään. Toisissa artikkeleissa kansainvälistä tutkimustietoa käytetään runsaasti, kun taas toisissa artikkeleissa lähteinä on käytetty lähinnä suomenkielisiä populaarimpia kirjoituksia ja internet-sivuja. Myös sosiaalisen median jatkuva kehittyminen ja tiettyjen aihepiirien akateemisen tutkimuksen vähyys ovat asettaneet haasteensa kirjoittajille ja kirjan toimittajille. Tämä näkyy joissain kirjassa käytetyistä sanavalinnoista, joista välittyy, että aiheesta ei vielä tiedetä riittävästi. Lukijalle tällaiset "näppituntumalta voidaan sanoa" (s. 22) tai "sellainen käsitys on yleisesti syntynyt" (s. 24) -ilmaisut voivat kuitenkin olla haasteellisia tiedon luotettavuuden arvioinnin kannalta.

Kaiken kaikkiaan Twitter viestintänä: Ilmiöt ja verkostot -kirja antaa lukijalleen sen minkä otsikossaan lupaa. Suurin osa kirjan artikkeleista keskittyy Twitteriin yksisuuntaisena tiedotustai viestintäkanavana, eikä sosiaalisen median vuorovaikutusketjuja tai keskusteluun osallistujien roolia keskusteluaiheiden valinnalle tai vuorovaikutuksen kehittymiselle juurikaan analysoida. Tämä on toki ymmärrettävää myös siitä näkökulmasta, että Twitterin käyttö etenkin julkisuuden henkilöiden (kuten politiikko- 
jen) osalta perustui varsinkin Twitterin alkuaikoina vahvasti heidän julkaisujensa passiiviseen seuraamiseen ja yksisuuntaiseen tiedottamiseen ja vasta viime vuosina suomalaisten Twitterin käyttö on muuttunut vuorovaikutteisem maksi. Kirjan luvut tarjoavat kuitenkin paljon perustietoa etenkin Twitterin aktiivisista suo malaiskäyttäjistä sekä tietyntyyppisistä organisaatioista Twitterissä ja herättävät ajankohtaist keskustelua sosiaalisen median alustojen ilmiöistä ja niiden hyödyntämisestä tutkimuskäyttöön.

Kirja tarjoaakin ensimmäisen ja varsin tarpeellisen suomenkielisen katsauksen Twitterin käyttöön eri konteksteissa. Siitä hyötyvät varmasti niin viestinnän kuin lähitieteidenkin opiskelijat ja tutkijat ja kirjan artikkeleista löytyy hyödyllisiä ja uusia näkökulmia myö ammatillisen sosiaalisen median käytön kontekstiin. Esimerkiksi kirjan tutkimusosioss nostetaan esiin kiinnostavia teemoja tunnetilojen tunnistamiseen Twitterissä (luku 13) jota voisi hyödyntää niin yritysten asiakaskokemuksen kuin henkilöstötyytyväisyydenkin analysoimiseen. Kirjan teemojen osittainen hajanaisuus ei haittaa lukijaa etenkään silloin, jos yksittäisiä lukuja luetaan itsenäisesti, tiettyyn osa-alueeseen keskittyen. Esimerkiksi opinnäytetöiden tekijöille tiettyyn teemaan keskittyvät luvut tarjoavat helppolukuista tietoa. Lisäks erityisesti ne kirjan luvut, joissa perehdytään Twitterin käytön periaatteisiin ja logiikkaan sekä erilaisiin mainekriiseihin tai poliittiseen vaikuttamiseen, olisivat erityisen suositeltavia luettavia kaikille Twitteriä käyttäville tai käytön aloituksesta kiinnostuneille.

Puheviestinnän näkökulmasta kirjaa voi tarkastella taustoituksena monille vuorovaikutuksen ilmiöille sosiaalisessa mediassa. Vaikka

Twitterin vuorovaikutteisuus ja se, miten merkityksiä ja todellisuutta sosiaalisen median kes- kusteluissa rakennetaan jääkin kirjassa hiukan paitsioon, voi kirja kuitenkin toimia vuorovaikutuksen asiantuntijoille ajatusten herättelijän Twitterin mahdollisuuksista erilaisten käyttäjien yhteisenä vuorovaikutusalustana. Lisää tutkimusta tarvittaisiin kuitenkin siitä, miten Twitterissä tai muussa sosiaalisessa mediassa rakennetaan yhteisiä merkityksiä tai hallitaan ammatillisia identiteettejä ja mielikuvia, tai miten vaikkapa erimielisyyksiin suhtaudutaan ja niitä ratkotaan hyvin eri taustoista tulevien ihmisten Twitter-keskusteluissa. 